Jurnal Pendidikan Matematika : Judika Education

Volume 1, Nomor 1, Januari-Juni 2018

e-ISSN : 2614-6088

p-ISSN : 2620-732X

DOI: https://doi.org/10.31539/judika.v1i1.280

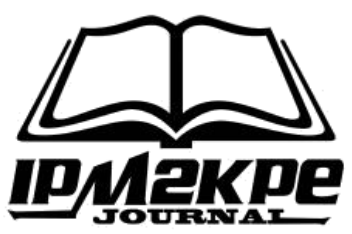

\title{
PENINGKATAN KETUNTASAN \\ HASIL BELAJAR MATEMATIKA MENGGUNAKAN \\ MODEL COOPERATIVE LEARNING TIPE STAD MELALUI \\ PEMANFAATAN ALAT PERAGA
}

\author{
Bambang Winarto \\ SMK Negeri 3 Probolinggo \\ bambang_winarto@yahoo.com
}

\begin{abstract}
ABSTRAK
Tujuan penelitian ini untuk meningkatkan ketuntasan belajar siswa kelas XI SMK Negeri 3 menggunakan model cooperative learning tipe STAD melalui pemanfaatan alat peraga. Penelitian ini menggunakan pendekatan deskriptif kualitatif dan kuantitatif serta jenis penelitian ini adalah penelitian tindakan kelas. Metode pengumpulan data menggunakan observasi, tes dan dokumentasi. Hasil yang diperoleh dalam penelitian ini adalah hasil belajar siswa. Hal ini menunjukkan bahwa dalam kegiatan belajar mengajar dengan pembelajaran kontekstual siswa menjadi sangat aktif. Sedangkan ketuntasan belajar siswa secara klasikal pada siklus I mencapai $77,5 \%$ meningkat di siklus II menjadi $90 \%$ sehingga hanya beberapa siswa yang belum tuntas belajarnya. Hal ini menunjukkkan bahwa pembelajaran kooperatif tipe STAD dapat dipertimbangkan sebagai model pembelajaran yang digunakan oleh guru. Berdasarkan hasil analisis data dan pembahasan, dengan diterapkannya pembelajaran Kooperatif Tipe STAD dapat meningkatkan hasil belajar siswa, penerapan metode tersebut dapat menarik perhatian siswa untuk mengikuti kegiatan belajar mengajar hingga akhir pelajaran dengan suasana belajar yang menyenangkan sehingga dapat menyebabkan meningkatnya hasil belajar siswa. Simpulan, terdapat peningkatan secara signifikan hasil belajar matematika siswa menggunakan model cooperative learning tipe STAD melalui pemanfaatan alat peraga.
\end{abstract}

Kata Kunci: Hasil Belajar, Pembelajaran Kooperatif, TIPE STAD.

\begin{abstract}
The purpose of this study was to improve the mastery learning of Grade XI students of SMK Negeri 3 using the cooperative learning model type STAD through the use of teaching aids. This study uses descriptive qualitative and quantitative approaches and this type of research is classroom action research. Data collection methods use observation, tests and documentation. The results obtained in this study are student learning outcomes. This shows that in teaching and learning activities with contextual learning students become very active. While the mastery learning of students classically in the first cycle reached $77.5 \%$, increasing in the second cycle to $90 \%$ so that only a few students have not yet completed their studies. This shows that STAD type cooperative learning can be considered as a learning model used by teachers. Based on the results of data
\end{abstract}


analysis and discussion, the implementation of STAD Cooperative learning can improve student learning outcomes, the application of these methods can attract the attention of students to participate in teaching and learning activities until the end of the lesson with a pleasant learning atmosphere so that it can lead to increased student learning outcomes. Conclusion, there is a significant increase in student mathematics learning outcomes using the cooperative learning model type STAD through the use of teaching aids.

Keywords: Learning Outcomes, Cooperative Learning, TYPE STAD.

\section{PENDAHULUAN}

Pembelajaran merupakan suatu proses dimana lingkungan seseorang secara sengaja dikelola untuk memungkinkan ia turut serta dalam kondisi-kondisi khusus atau menghasilkan respon terhadap situasi tertentu (Miarso dalam Aunurrahman, 2009). Gagne (dalam Aunurrahman, 2009) mendefinisikan pembelajaran sebagai "seperangkat acara peristiwa eksternal yang dirancang untuk mendukung terjadinya beberapa proses belajar yang sifatnya internal".

Dari pengertian pembelajaran tersebut menunjukkan bahwa pembelajaran berpusat pada kegiatan siswa belajar dan bukan berpusat pada kegiatan guru mengajar. Pada hakekatnya pembelajaran matematika adalah suatu proses yang dirancang secara sengaja dengan tujuan untuk menciptakan suasana lingkungan yang memungkinkan siswa melaksanakan kegiatan belajar matematika, dan proses tersebut berpusat pada guru mengajar matematika. Pembelajaran matematika harus memberikan peluang kepada siswa untuk berusaha dan mencari pengalaman tentang matematika.
Rendahnya hasil belajar matematika peserta didik dikarenakan sulitnya pemahaman terhadap materi, media pembelajaran yang kurang mendukung khususnya dalam menggunakan alat peraga untuk mempermudah pemahaman peserta didik terhadap materi.

Sehingga peserta didik kurang bisa mengenal obyek metematika secara langsung tetapi hanya secara abstrak. Salah satu usaha peneliti untuk meningkatkan hasil belajar peserta didik dapat diatasi dengan menerapkan metode yang lebih meningkatkan keefektifan belajar peserta didik.

Salah satu alternatif model pembelajaran dalam K13 adalah model pembelajaran Cooperative Learning. Model ini juga biasa disebut model pembelajaran gotong royong. Sifat pembelajaran Cooperative Learning tidak sama dengan pembelajar kelompok atau pembelajar bekerja sama biasa. Salah satu model Cooperative Learning adalah metode STAD (Student Teams Achievement Divisions).

STAD merupakan model pembelajaran kooperatif untuk 
pengelompokan peserta didik secara heterogen yang melibatkan pengakuan tim dan tanggung jawab kelompok untuk pembelajaran individu anggota. Tujuan dari pembelajaran ini adalah memberi pembelajaran kepada peserta didik untuk mampu berinteraksi dengan peserta didik lain dalam satu kelompok dalam menyelesaikan permasalahan dan bertanggung jawab atas pembelajaran individu anggota.

$$
\text { Pembelajaran Kooperatif }
$$

(Cooperative Learning) adalah salah satu bentuk pembelajaran yang berdasarkan faham kontsruktivis. Cooperative learning merupakan strategi belajar dengan sejumlah siswa sebagai anggota kelompok kecil yang tingkat kemampuannya berbeda. Dalam menyelesaikan tugas kelompoknya, setiap siswa anggota kelompok harus saling bekerja sama dan saling membantu untuk memahami materi pelajaran.

Dalam Cooperative learning, belajar belum dikatakan selesai jika salah satu teman dalam kelompok belum menguasai bahan pelajaran (Isjoni, 2009). Salah satu contoh model pembelajaran kooperatif adalah model pembelajaran STAD. STAD merupakan salah satu model dari pembelajaran kooperatif untuk pengelompokan campur yang melibatkan pengakuan tim dan tanggung jawab kelompok untuk pembelajaran individu anggota.

Student Team Achievement Divisions (STAD) adalah salah satu tipe pembelajaran kooperatif yang paling sederhana. Siswa ditempatkan dalam tim belajar beranggotakan empat orang yang merupakan campuran menurut tingkat kinerjanya, jenis kelamin dan suku. Guru menyajikan pelajaran kemudian siswa bekerja dalam tim untuk memastikan bahwa seluruh anggota tim telah menguasai pelajaran tersebut.

Alat peraga adalah alat (benda) yang digunakan untuk memperagakan fakta, konsep, prinsip, atau prosedur tertentu agar tampak lebih nyata/ konkrit (Rahadi, 2004). Alat peraga yaitu alat untuk menerangkanatau mewujudkan konsep Matematika.

Benda-benda itu misalnya batubatuan dan kacang-kacangan untuk menerangkan konsep bilangan; kubus(bendanya) untuk menjelaskan konsep titik, ruas garis, daerah bujursangkar, dan wujud dari kubus itu sendiri; benda-benda bidang beraturanuntuk menerangkan konsep pecahan; benda-benda seperti cincin, gelang,permukaan gelas, dan sebagainya untuk menerangkan konsep lingkaran dan sebagainya (E.T.Ruseffendi dalam Rahadi, 2004). Alat peraga adalah alat (benda) yangdigunakan untuk memperagakan fakta, konsep, prinsip, atau prosedurtertentu agat tampak lebih nyata atau konkrit (Rahadi 2004).

Untuk mengetahui penerapan model pembelajaran cooperative learning tipe STAD melalui pemanfaatan alat peraga terhadap hasil belajar peserta didik, peneliti tertarik untuk mengetahui Bagaimana 
penerapan model pembelajaran matematika cooperative learning tipe STAD melalui pemanfaatan alat peraga pada sub materi pokok Relasi dan Fungsi terhadap hasil belajar peserta didik kelas XI Jurusan Tata Boga semester I SMK Negeri 3 Kota Probolinggo tahun pelajaran 2017/2018. Penelitian ini dibatasi kurun waktu tertentu yaitu pada sub materi pokok Relasi dan Fungsi kelas XI Jurusan Tata Boga semester I tahun pelajaran 2017/2018.

Peneliti tertarik meneliti lebih jauh penggunaan metode pembelajaran Cooperative Learning tipe STAD Melalui pemanfaatan alat peraga pada sub materi pokok relasi dan fungsi untuk melihat adakah peningkatan hasil belajar siswa dilihat dari ketuntasan siswa dalam pembelajaran matematika.

Kelebihan

penerapan

menggunakan metode Koopertif tipe STAD ini agar siswa mampu berinteraksi dan meningkatkan kecakapan secara individu maupun kelompok, memiliki sikap bertanggung jawab dan menimbulkan sikap karakter disiplin, bekerjasama, dan saling menghormati.

\section{METODE PENELITIAN}

Dalam kegiatan penelitian ini menggunakan pendekatan kualitatif karena hasil penelitian akan berupa kata-kata yaitu digunakan untuk mengamati dan menganalisis temuan apa saja yang diperoleh setelah guru menerapkan pembelajaran tipe STAD.
Jenis penelitian ini menggunakan penelitian tindakan kelas (PTK). Penelitian Tindakan Kelas (PTK) termasuk penelitian kualitatif, meskipun data yang dikumpulkan dapat bersifat kuantitatif, dimana uraiannya bersifat deskriptif dalam bentuk kata-kata, peneliti merupakan instrumen utama dalam pengumpulan data.

Menurut Arikunto desain Penelitian yang mengemukakan model penelitian tindakan dengan bagan yang berbeda, namun secara garis besar terdapat empat tahapan yang lazim dilalui, yaitu perencanaan, (2) pelaksanaan, (3) pengamatan, dan (4) refleksi. Penelitian ini menggunakan dua siklus, jika siklus pertama sudah mencapai hasil yang diinginkan maka siklus dilanjutkan kesiklus kedua dengan materi selanjutnya.

Tetapi jika belum, maka dilanjutkan siklus kedua dengan materi selanjutnya. Apabila siklus pertama sudah dilaksanakan maka dapat diketahui keberhasilan atau hambatan dari siklus pertama. Maka dengan diketahuinya keberhasilan atau hambatan dari siklus pertama, maka peneliti dapat melakukan perbaikan pada siklus keduanya. Diterapkannya dua siklus pada penilitian ini adalah untuk menyakinkan hasil penelitian

Arikunto (2006) menjelaskan jika metode pengumpulan atau perolehan data adalah bagaimana peneliti menentukan metode setepattepatnya untuk memperoleh data. 
Adapun metode yang digunakan dalam penelitian ini adalah: observasi, wawancara atau interview dan tes akhir.

Dalam penelitian ini analisis data yang dilakukan adalah deskriptif kualitatif dan kuantitatif. Analisa data kualitatif pada penelitian ini adalah analisa data yang diperoleh dari hasil observasi dan wawancara yang dimulai dari kegiatan pendahuluan sampai siklus berakhir. Sedangkan analisa data kuantitatif pada penelitian ini adalah data yang berupa angkaangka dari data yang diperoleh dari tes dan observasi.

\section{HASIL PENELITIAN}

\section{Siklus I}

Perencanaan

Dari hasil identifikasi permasalahan pada siswa sebelum tindakan kelas dilakukan, maka diambil tindakan untuk memecahkan permasalahan tersebut yaitu dengan menerapkan pembelajaran menggunakan metode STAD. Langkah selanjutnya yaitu mempersiapkan instrumen penelitian antara lain: a) menyusun silabus dan Rencana Pelaksanaan Pembelajaran (RPP) siklus I, b) menyiapkan Lembar Kegiatan Peserta Didik (LKPD), c) membuat pedoman observasi, d) mempersiapkan instrumen penilaian

\section{Pelaksanaan Tindakan}

Pada tahap ini dilaksanakan tindakan pembelajaran dengan menggunakan metode STAD pada materi lingkaran dalam dan lingkaran luar segitiga. Dimana tindakan disini mengacu pada Rencana Pelaksanaan Pembelajaran yang dibagi menjadi 3 tahap yaitu tahap awal, inti, dan penutup.

\section{Observasi (Pengamatan)}

Kegiatan observasi dilaksanakan bersama-sama dengan pelaksanaan tindakan. Kegiatan observasi dilakukan untuk mengetahui aktivitas siswa dan guru (peneliti) dalam proses belajar mengajar. Pada siklus I dan II, peneliti dibantu oleh guru bidang studi matematika yang bertugas mengamati aktivitas guru (peneliti) dan tiga observer yang bertugas mengamati aktivitas siswa selama proses pembelajaran.

Pada siklus I, kegiatan pembelajaran diawali dengan pengenalan diri oleh peneliti dan observer kepada siswa. Setelah melakukan pengenalan, guru (peneliti) membagi siswa menjadi 8 kelompok dengan masing-masing kelompok terdiri dari 5 siswa. Pada kegiatan observasi individu, observer melihat siswa kurang aktif, baik dalam bertanya, bekerja kelompok, perhatian terhadap pelajaran, menjawab pertanyaan maupun presentasi. Hal ini disebabkan siswa harus beradaptasi dengan teman satu kelompok.

\section{Refleksi}

Tujuan diadakan tes akhir ini adalah untuk mengetahui seberapa dalam siswa menguasai materi 
lingkaran dalam dan lingkaran luar segitiga. Guru membagikan soal tes akhir. Dari permasalahan yang ada akan diadakan perbaikan baik terhadap cara pembelajaran yang akan dilaksanakan ataupun dari siswa yang menjadi peserta didik, misalnya dilakukan sosialisasi kembali metode STAD ini kepada siswa dan memperbaiki cara penyajian materi. Semua hal diatas akan dilaksanakan pada siklus ke II dengan perencanaan yang lebih baik sehingga diharapkan pada siklus II semua siswa mendapat hasil belajar seperti yang diharapkan.

\section{Siklus II}

Dalam pelaksanaan siklus II (dua) penelitian ini dalam tahap perencanaan, pelaksanaan tindakan, dan observasi disiklus II hampir sama dengan perencanaan , pelaksanaan tindakan, dan observasi yang dilakukan di siklus I. Namun yang membedakan adalah pemberian materi yang digunakan dalam siklus II adalah kelanjutan materi pembelajaran pokok bahasan setelah di ajarkandi siklus I.

\section{Refleksi}

Dari hasil belajar dan observasi yang diperoleh siswa pada siklus II ini menunjukkan sudah lebih baik dari siklus I dan nilai secara individu dan klasikal sudah mengalami peningkatan yang cukup memuaskan. Akan tetapi ada beberapa hal yang masih perlu diperbaiki yaitu hendaknya guruharus pandai untuk menguasai kondisi siswa saat pelajaran berlangsung, karena jika tidak siswa akan terbawa suasana yang menyebabkan kondisi siswa sulit dikendalikan atau dikontrol.

Meskipun masih ada beberapa kekurangan pada saat proses pembelajaran pada siklus II, namun secara umum hasil yang dicapai sudah baik dalam arti tujuan dalam penelitian ini sudah tercapai.

Pembelajaran dengan metode STAD cukup berhasil pada mata pelajaran matematika di SMK Negeri 3 kelas XI. Ini bisa terlihat dari hasil tes yang dilakukan siswa dan hasil observasi, aspek kognitif diperoleh dari hasil tes, pada siklus I diperoleh siswa yang tuntas secara individu sebanyak 31 siswa dan yang tidak tuntas hanya 9 orang siswa atau secara klasikal siswa yang tuntas adalah sebanyak 77,5\% untuk aspek kognitif, pada aktivitas siswa ketuntasan belajar siswa secara klasikal mencapai $90 \%$ dan pada aktivitas guru menunjukkan bahwa guru telah melaksanakan langkah-langkah pembelajaran dengan baik dan maksimal.

Nilai hasil belajar pada siklus I sudah mengalami peningkatan dibandingkan dengan nilai yang lalu pada materi Relasi dan Fungsi yaitu ketuntasan secara klasikal sebesar $77,5 \%$. Akan tetapi pada siklus I nilai ketuntasan klasikal belum mencapai sandart ketuntasan yang ditetapkan oleh sekolah. Oleh karena itu peneliti perlu melanjutkan kembali pembelajaran pada materi yang sama dengan siklus II. Setelah diadakan tes, hasil belajar siswa mengalami 
peningkatan dan memenuhi target standar ketuntasan dari sekolah sebesar $90 \%$.

\section{PEMBAHASAN}

Student Team Achievement Divisions (STAD) adalah salah satu tipe pembelajaran kooperatif yang paling sederhana. Siswa ditempatkan dalam tim belajar beranggotakan empat orang yang merupakan campuran menurut tingkat kinerjanya, jenis kelamin dan suku.

Guru menyajikan pelajaran kemudian siswa bekerja dalam tim untuk memastikan bahwa seluruh anggota tim telah menguasai pelajaran tersebut. Akhirnya seluruh siswa dikenai kuis tentang materi itu dengan catatan, saat kuis mereka tidak boleh saling membantu (Slavin, 2010).

Pembelajaran dengan metode STAD pada mata pelajaran matematika di SMK Negeri 3 kelas XI cukup berhasil. Dilihat dari aspek kognitif yang diperoleh dari hasil tes, nilai hasil belajar pada siklus I sudah mengalami peningkatan dibandingkan dengan nilai yang lalu pada materi Relasi dan Fungsi yaitu ketuntasan secara klasikal sebesar $77,5 \%$. Akan tetapi pada siklus I nilai ketuntasan klasikal belum mencapai sandart ketuntasan yang ditetapkan oleh sekolah. Oleh karena itu peneliti perlu melanjutkan kembali pembelajaran pada materi yang sama dengan siklus II. Setelah diadakan tes, hasil belajar siswa mengalami peningkatan dan memenuhi target standar ketuntasan dari sekolah sebesar $90 \%$.

Kegiatan yang dilakukan dalam pembelajaran matematika pada materi relasi dan fungsi pemaparan materi, guru memberikan permasalahanpermasalahan yang bersifat menggugah pemikiran siswa untuk mengembangkan pengetahuan yang dimiliki siswa dan guru mengaitkannya dengan materi yang akan diajarkan.

Jika selama ini siswa terbiasa langsung diberikan materi tanpa menstimulus siswa terlebih dahulu untuk mengarahkan siswa pada materi yang akan dipelajarinya, maka pada pertemuan pertama guru berinisiatif untuk memberi pertanyaan kepada seluruh siswa yang bertujuan untuk membimbing siswa mengarah pada materi yang akan dipelajari. Pemaparan materi dengan alat peragabentuk nyata dari bangun Relasi dan Fungsi.

Kemudian guru menjelaskan tentang metode pembelajaran yang akan dilakukan dan langkahlangkahnya, pada saat pelaksanaan metode pembelajaran STAD, tampak siswa masih kelihatan bingung apa yang akan dilakukan. Untuk itu guru kembali menjelaskan langkah-langkah penentuan rumus jari-jari Relasi dan Fungsi. Setelah siswa mengerti dan paham, maka terlihat siswa aktif dalam proses belajar mengajar, dan aktif dalam kerja kelompok.

Penilaian pada penelitian ini meliputi penilaian aspek kognitif yang 
diperoleh dari hasil tes atau ulangan harian, dan penilaian aktivitas siswa diperoleh pada proses belajar mengajar, penilaian aktivitas siswa dapat diperoleh pada saat pembelajaran dengan metode STAD, untuk pengambilan data tersebut peneliti dibantu 3 orang observer yang bertugas mengamati dan mengisi lembar observasi aktivitas siswa selama proses belajar mengajar berlangsung.

Metode STAD ini berbeda dengan pembelajaran yang biasa digunakan. Dalam pembelajaran konvensional, guru kurang melibatkan siswa dalam pembelajaran. Siswa terlihat pasif, hanya duduk, mendengarkan, dan mencatat. Kelebihan dalam penggunaan pendekatan pembelajaran STAD adalah sebagai berikut.

1. Mengembangkan

serta menggunakan keterampilan berpikir kritis dan kerja sama kelompok.

2. Menyuburkan hubungan antara pribadi yang positif diantara peserta didik yang berasal dari ras yang berbeda.

3. Menerapkan bimbingan oleh teman.

Kegiatan yang peneliti lakukan ini telah membuat suasana belajar menyenangkan dan lebih menarik, sebagian siswa tampak aktif mengikuti berbagai kegiatan yang harus dikerjakan oleh siswa. Meskipun diantara siswa masih ada yang tidak mendengarkan penjelasan guru sehingga guru tidak bisa mengontrol kelas dengan baik, dan pada saat diskusi siswa masih banyak yang bermain-main dalam berdiskusi. Tetapi itu juga dapat diatasi guru dengan membimbing siswa tersebut, baik secara individu maupun kelompok.

Hasil observasi pada siklus Idan siklus II terhadap aktivitas belajar siswa menunjukkan ketuntasan hasil belajar. Pada siklus I siswa kelas XI Jurusan Tata Boga mencapai ketuntasan sebesar 77,5\%, sedangkan pada siklus II mencapai ketuntasan sebesar $90 \%$.

Berdasarkan hasil analisis hasil observasi aktivitas siswa tersebut, maka dapat disimpulkan bahwa aktivitas siswa selama kegiatan belajar mengajar telah baik, karena telah mencapai ketuntasan klasikal yang melebihi standart ketuntasan minimal yang ditetapkan oleh SMK Negeri 3 Kota Probolinggo, yaitu $80 \%$ untuk ketuntasan klasikal dan 67 untuk ketuntasan individu. Siswa tampak sangat aktif pada saat kegiatan untuk menyelasaikan permasalahan yang ada.

Pada saat diskusi kelompok, nampak terjalin kerjasama antar anggota kelompok sesuai dengan LKPD (lembar kerja peserta didik). Melalui penerapan metode STAD, peneliti memperoleh beberapa temuan bahwa metode yang diberikan peneliti tersebut dapat memupuk kerjasama siswa dalam menemukan solusi dari 
sebuah permasalahan yang mereka hadapi.

\section{SIMPULAN}

Berdasarkan hasil penelitian dan pembahasan, maka dapat diambil simpulan jika Penerapan pembelajaran $S T A D$ dapat menciptakan suasana belajar yang menyenangkan dan tidak membosankan, sehingga siswa termotivasi untuk mengikuti kegiatan pembelajaran. Selain itu metode pembelajaran tersebut mampu menarik perhatian siswa untuk terlibat aktif dalam kegiatan pembelajaran dan siswa dapat merumuskan dan memecahkan masalah yang dihadapi. Dengan demikian, melalui penerapan metode tersebut dapat menarik perhatian siswa untuk mengikuti kegiatan belajar mengajar hingga akhir pelajaran dengan suasana belajar yang menyenangkan.

Penerapan pembelajaran STAD mampu menggunakan alat peraga meningkatkan hasil belajar matematika siswa. Hal ini terlihat dari adanya kenaikan ketuntasan klasikal pada tes akhir siklus II dibanding tes akhir pada siklus I. Pada siklus I terlihat ketuntasan klasikal mencapai $77,5 \%$ dan $90 \%$ pada siklus II. Jadi, penerapan metode STAD ini dapat meningkatkan hasil belajar siswa kelas XI Jurusan Tata BogaSMK Negeri 3 Kota Probolinggo.

\section{DAFTAR PUSTAKA}

Arikunto, S. (2006). Prosedur Penelitian Pendekatan Praktek. Jakarta: PT. RinekaCipta.

Aunurrahman. (2009). Belajar dan Pembelajaran. Bandung: Alfabeta.

Isjoni. (2009). Pembelajaran Kooperatif. Meningkatkan Kecerdasan Komunikasi Antar. Bandung: Alfabeta.

Rahadi, A. (2004). Media

Pembelajaran. Jakarta: Depdiknas.

Slavin. (2010). Cooperative Learning tipeSTAD,(online), (http://www.docstoc.com/docs/ 16101835/) 